\title{
PERANCANGAN SISTEM KONTROL OVER/UNDER VOLTAGE RELAY BERBASIS MIKROKONTROLER PADA SALURAN TEGANGAN 220VAC
}

\author{
Billy Mahdianto Arsyad*), Aghus Sofwan, Agung Nugroho \\ Departemen Teknik Elektro, Universitas Diponegoro \\ J1. Prof. Sudharto, SH, Kampus UNDIP Tembalang, Semarang 50275, Indonesia \\ ${ }^{*}$ E-mail:billymahdianto@gmail.com
}

\begin{abstract}
Abstrak
Gangguan distribusi listrik mengakibatkan terhambatnya aktivitas manusia sehari-hari. Gangguan yang terjadi dapat berbagai macam antara lain adalah lonjakan atau penurunan tegangan listrik (over/under voltage) dan ketidakstabilan tegangan listrik. Untuk itu dibuatlah perancangan sistem kontrol over/under voltage relay ini menggunakan mikrokontroler STM32F103C8T6 dengan aktuatornya berupa relay. Keluaran tegangan rata-rata pada regulator untuk suplai mikrokontroler adalah 3.31 V dan 5V. Untuk membaca nilai tegangan AC dari keluaran variable transformator atau listrik normal menggunakan sensor ZMPT101B yang menggunakan penundaan T/4OSG (Orthogonal Signal Generator). Pengaturan gain yang dilakukan pada sensor sebesar VPP $=0,72 \mathrm{~V}$ dilakukan pada tegangan terukur VAC $=210 \mathrm{~V}$, dimana nilai VPP adalah tegangan puncak antara positif dengan negatif gelombang keluaran ZMPT101B. Gelombang tersebut berosilasi pada nilai minimum 1,32 V dan nilai maksimum 2,040 V dengan titik offset VDC sebesar 1,677V. Nilai offset ini tidak bernilai 1,65V dikarenakan menyesuaikan tegangan referensi mikrokontroler. Metode kontrol yang digunakan adalah metode on/off pada relay. Keluaran alat menunjukkan 3 kondisi yaitu under voltage dimana tegangan dibawah $216 \mathrm{~V}$, normal voltage tegangan $216 \mathrm{~V}-224 \mathrm{~V}$, dan over voltage tegangan diatas $224 \mathrm{~V}$. Hasil dari pembacaan sensor dan kondisi akan dikirimkan melalui internet ke database dengan mengunakan adalah ESP-01. Dari hasil pengujian menunjukkan sistem telah berjalan sesuai rancangan
\end{abstract}

Kata Kunci: Over/Under Voltage Relay, Sensor ZMPT101B, Relay, Mikrokontroler STM32F103C8T6, Metode kontrol on-off, ESP-O1

\begin{abstract}
The occurrence of electricity distribution disruption will disturb human daily activities. The disruption can be caused by surging of electricity (over / under voltage) and voltage instability. Therefore, over/under voltage relay control system was designed using STM32F103C8T6 microcontroller with relay as the actuator. The average voltage outputs for microcontroller supply are 3.31V and 5V. ZMPT101B sensor with T/4 OSG delay (Orthogonal Signal Generator) was used to read $\mathrm{AC}$ voltage values from variable transformer or normal electrical output. The sensor gain setting was VPP = $0.72 \mathrm{~V}$ set at $\mathrm{VAC}=210 \mathrm{~V}$, where the VPP is the peak voltage between positive and negative wave output of ZMPT101B. The wave oscillates between $1.32 \mathrm{~V}-2.040 \mathrm{~V}$ with $1.677 \mathrm{VDC}$ offset point. This offset value is different with $1.65 \mathrm{~V}$ to adapt to microcontroller reference voltage. The on/off method was used for relay control method. The device output show 3 conditions: under voltage where the voltage less than $216 \mathrm{~V}$, normal voltage where the voltage is between $216 \mathrm{~V}$ and $224 \mathrm{~V}$, and over voltage where the voltage is greater than $224 \mathrm{~V}$. The sensor reading results were sent via internet to the database using ESP-01. The result shows that the system has been working properly.
\end{abstract}

Keywords:: Over/Under Voltage Relay, Sensor ZMPT101B, Relay, Microcontroller STM32F103C8T6, on-off control method, ESP-01

\section{Pendahuluan}

Seluruh aktivitas manusia tak terlepas dari penggunaan energi listrik. Kebutuhan energi listrik untuk masyarakat di seluruh Indonesia akan terus meningkat, sehingga diperlukan suplai tenaga listrik yang mencukupi. Tercatat, penjualan tenaga listrik PLN tahun 2017 sebesar 219.544,60 GWh. Dibandingkan dengan tahun 2016 penjualan tenaga lsitrik tersebut naik sebesar 3.540,28
GWh atau 1,6\% terdiri dari penjualan untuk sektor industri sebesar 71.744,13 GWh, sektor rumah tangga sebesar 93.583,52 GWh, sektor komersial atau usaha sebesar 41.601,08 GWh, sektor publik atau umum sebesar 3.503,47 GWh, dan sektor sosial dan kantor pemerintah sebesar 11.142,47 GWh[1]. Selain dari kecukupan pasokan listrik, masyarakat juga membutuhkan kestabilan dan kehandalan dari distribusi listrik itu sendiri. Sehingga apabila terdapat gangguan distribusi listrik akan berakibat 
terhambatnya aktivitas sehari-hari. Maka dari itu, PT. PLN (persero) sebagai satu-satunya pendistribusi listrik ke masyarakat dituntut untuk dapat memberikan distribusi listrik yang stabil dan handal.

Adanya gangguan dalam suplai listrik dapat mempengaruhi bahkan merusak suatu sistem tenaga listrik [2]. Gangguan yang terjadi dapat berbagai macam antara lain adalah lonjakan atau penurunan tegangan listrik (over/under voltage) [3]. Jika gangguan tegangan ini tersambung ke peralatan listrik atau elektronika dan melebihi batas toleransi tegangan nominalnya, maka hal itu dapat mengganggu kinerja peralatan-peralatan tersebut atau bahkan dapat merusaknya. Dan gangguan seperti itu tidak hanya merugikan konsumen tetapi juga merugikan produsen tenaga listrik. Dalam aturan distribusi tenaga listrik dijelaskan bahwa untuk under voltage yaitu $-10 \%$ dari tegangan normal, sedangkan untuk over voltage yaitu $+5 \%$ dari tegangan normal [4]. Maka dari itu dibutuhkan suatu sistem yang dapat mengidentifikasi gangguan tegangan tersebut secara real time sehingga dapat dipantau secara langsung dari lapangan dan selanjutnya data disimpan pada database. Pada penelitian ini dirancang sebuah sistem untuk mendeteksi kestabilan tegangan menggunakan sebuah sensor tegangan yaitu ZMPT101B yang diprogram agar dapat mendeteksi tegangan 1 fasa [5]. Alat ini juga dapat menampilkan data tersebut secara real time dengan mengirimkan data itu ke server sehingga dapat dilakukan pemantauan jarak jauh menggunakan ESP-01[6] Mikrokontroler yang digunakan adalah ARM seri STM32F103C8T6[7]. Pada mikrokontroler akan digunakan 3 indikator yang bisa menjadi acuan kondisi kestabilan jaringan yang terpasang alat tersebut yaitu indikator over voltage, under voltage dan normal voltage dengan settingan yang diinginkan.

Penelitian ini memberikan kontribusi untuk membantu pekerjaan tim distribusi listrik di PLN untuk mengetahui nilai dan status tegangan sebagai suplai $220 \mathrm{v}$ secara real time, dan dapat dipantau secara remote melalui smartphone berbasis android.

\section{Metode}

Dalam bagian ini akan digambarkan secara rinci metoda penelitian yang dilakukan. Langkah-langkah yang dilakukan adalah merancang perangkat keras, merancang algoritma dan diagram alir system, dan merancang perangkat lunak.

\subsection{Perancangan Perangkat Keras}

Secara garis besar sistem terdiri atas 3 blok utama yaitu terdiri atas unit masukan, unit proses, dan unit keluaran, seperti diperlihatkan pada Gambar 1, yang dijabarkan sebagai berikut.

Bagian pertama adalah unit masukan dari alat yang dirancang. Pada alat ini digunakan sensor tegangan dengan jenis modul. Fungsi sensor tegangan ini adalah untuk mendeteksi kondisi tegangan saluran yang diamankan apakah normal, apakah terjadi kenaikan atau penurunan tegangan yang melebihi toleransi yang diijinkan. Setelah dideteksi maka nilai tegangan akan dikirim ke mikrokontroler untuk dilakukan proses data.

Bagian kedua dari sistem ini adalah unit pemrosesan data tegangan dalam bentuk pemograman. Alat yang digunakan yaitu mikrokontroler ARM sebagai pengolah data dan pengontrol hasil data dari inputan. Selanjutnya hasil yang diproses akan dikirim lagi ke beberapa komponen untuk mengetahui output dari program tersebut. Hasil dari proses program tersebut akan mengendalikan relay sebagai proteksi tegangan apabila terjadi under/over voltage. Pada mikrokontroller ARM dibuat setting batasan tegangan under voltage, over voltage, dan delay dalam pengambilan data. Dalam aturan distribusi tenaga listrik dijelaskan bahwa untuk under voltage yaitu $-10 \%$ dari tegangan normal, sedangkan untuk over voltage yaitu $+5 \%$ dari tegangan normal. Akan tetapi batasan tegangan dalam satu gangguan yang dibuat dalam penelitian ini yaitu: untuk gangguan over voltage $+5 \mathrm{~V}$ dan untuk gangguan under voltage sebesar $5 \mathrm{~V}$.

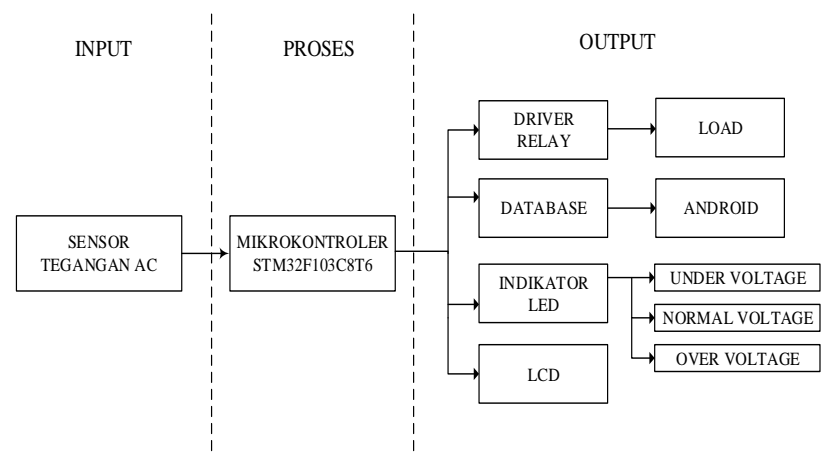

Gambar 1. Perancangan Sistem

Selanjutnya unit keluaran mempunyai prinsip-prinsip kerja sebagai berikut.

- Relay akan bekerja ketika output dari mikrokontroler ARM adalah tegangan yang dianggap sebagai gangguan yaitu terjadinya drop tegangan atau lonjakan tegangan yang melebihi settingan pada program.

- Lampu indikator merah sebagai indikasi untuk gangguan over voltage.

- Lampu indikator hijau sebagai indikasi untuk tegangan normal.

- Lampu indikator kuning sebagai indikasi untuk gangguan under voltage.

- LCD sebagai tampilan dari pembacaan tegangan yang masuk.

Dalam pemograman yang disetting pada mikrokontroler, alat ini dapat memberikan output seperti tampilan LCD, lampu indikator kondisi tegangan dan driver relay. Secara khusus program tersebut juga dapat mengirimkan data yang di proses ke database yang dapat dilihat menggunakan android. Pengiriman data dari 
mikrokontroler dibantu dengan modul mikroprosesor WiFi yang disebut dengan modul ESP-01.

Berikut ini akan dijelaskan perancangan dari sensor-sensor masukan, pengolah data, dan unit keluaran dari sistem yang dirancang.

\subsubsection{Perancangan Sensor ZMPT101B}

Modul sensor tegangan ZMPT101B adalah sensor tegangan yang terbuat dari transformator tegangan ZMPT101B. Sensor ini memiliki akurasi tinggi, konsistensi yang baik untuk voltase dan tenaga pengukuran dan bisa mengukur sampai $250 \mathrm{~V}$ AC. Sensor ini mudah untuk digunakan dan dilengkapi dengan multi turn trimmer potensiometer untuk menyesuaikan output ADC. Untuk dapat menemukan hasil yang lebih antara tegangan input dan output ADC menggunakan analisis regresi. Output ADC disesuaikan dengan trimpot ke nilai yang sesuai terhadap masukan referensi [8].

Perhitungan untuk menghasilkan nilai tegangan dari hasil pembacaan tegangan AC dapat menggunakan rumus :

$$
\begin{aligned}
& V_{\text {peak }}=\sqrt{2} V_{R M S} \\
& V_{R M S}=\frac{V_{\text {peak }}}{\sqrt{2}}
\end{aligned}
$$

Data yang masuk ke mikrokontroler akan diolah menjadi data penampil tegangan rms AC keluaran variable transformator. Gambar 2 menunjukkan konfigurasi pin sensor ZMPT101B.

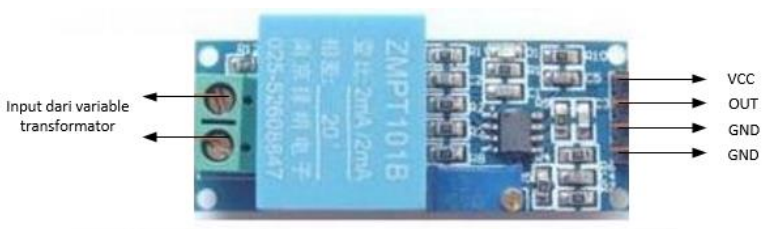

Gambar 2. Konfigurasi pin sensor ZMPT101B

\subsubsection{Perancangan STM32F103C8T6}

Mikrokontroler yang digunakan adalah STM32F103C8T6 dari ST® Electronics dengan basis ARM ${ }^{\circledR}$ Cortex-M3 dalam platform BluePill. STM32F103C8T6 adalah mikrokontroler 32-bit Reduce Instruction Set Computing (RISC) buatan STMicroelectronics yang memiliki arsitektur dan berbasis prosesor ARM® Cortex-M3 [7].

Tabel 1 mendeskripsikan konfigurasi input dan output yang dipakai pada penelitian ini. Pin PB1 digunakan untuk menerima data analog dari ZMPT101B sebagai pembacaan data tegangan AC dari keluaran variable transformator ataupun dari listrik PLN. Pin PB15 digunakan untuk memberikan sinyal digital untuk mengatur keadaan pada relay. Sistem pengontrolan menggunakan metode on-off sesuai dengan batasan yang dibuat. Pada Pin PB12 disambungkan dengan led kuning sebagai indikator under voltage, sedangkan pada Pin PB13 disambungkan dengan led hijau sebagai indikator normal voltage, serta Pin PB14 disambungkan dengan led merah sebagai indikator over voltage. Ketiga led ini diberi pengaturan dengan active high atau led akan menyala apabila diberi output tegangan dari mikrokontoler 3.3V (high). Pin PB10 dan PB11 digunakan sebagai komunikasi serial untuk mengirimkan data ke server database melali Wi-Fi. Sedangkan pada pin PB6 dan PB7 sebagai komunikasi serial master slave untuk menampilkan data pada LCD.

Tabel 1. Penempatan pin-pin IO pada papan mikrokontroler

\begin{tabular}{llll}
\hline I/O & Sinyal & Jenis & \multicolumn{1}{c}{$\begin{array}{c}\text { Pin pada } \\
\text { mikrokontroler }\end{array}$} \\
\hline Input & Sensor ZMPT101B & Analog & PB1 \\
Output & Modul Relay & Digital & PB15 \\
Output & Led Over & Digital & PB14 \\
Output & Led Normal & Digital & PB13 \\
Output & Led Under & Digital & PB12 \\
Output & Modul ESP-01 & Serial UART & PB10 (Tx), PB11 \\
& & & (Rx) \\
Output & LDC I2C & Serial & PB6, PB7 \\
\hline
\end{tabular}

\subsubsection{Perancangan Driver Relay}

Relay memerlukan supply 5-7.4V dari buck converter. Kabel sinyal dihubungkan ke pin PB15 pada mikrokontoler untuk mengirimkan sinyal digital untuk pengaktifan. Gambar 3 menunjukkan pemasangan relay menggunakan kondisi NC (Normally Close). Pada saat NC ini, kondisi awal dari relay sebelum diaktifkan oleh mikrokontroler akan selalu tersambung atau tegangan mengalir sehingga dapat menyalakan lampu. Setelah relay diaktifkan, maka relay akan memutuskan tegangan dan lampu akan mati. Modul relay ini akan aktif bila diberi digital output high atau tegangan $5 \mathrm{~V}$ dari mikrokontroler dan sebaliknya.

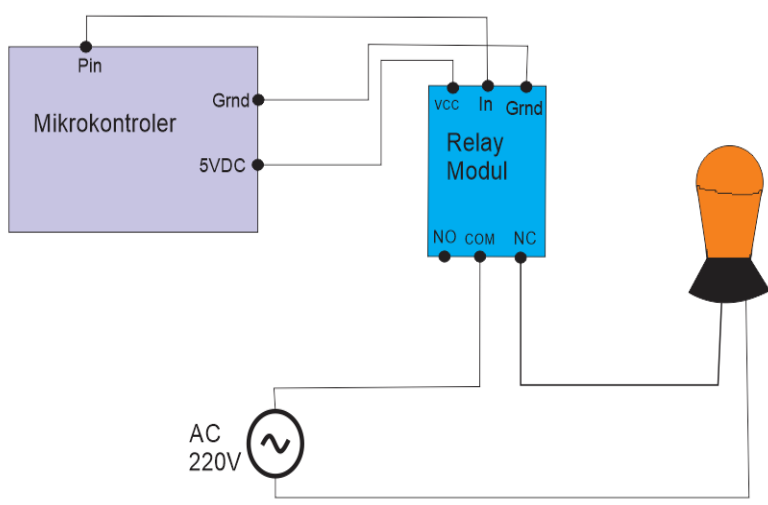

Gambar 3. Konfigurasi relay

\subsubsection{Perancangan Rangkaian ESP-01}

ESP-01 dalam alat ini digunakan sebagai alat komunikasi antara mikrokontroler dengan server database melalui jaringan Wi-Fi. Pada komponen ESP-01 memiliki kaki sebanyak delapan (8) buah sehingga dibutuhkan sebuah 
rangkaian sederhana untuk mengubungkan ESP-01 dengan mikrokontroler dan catu daya yang ditunjukkan pada Gambar 4.

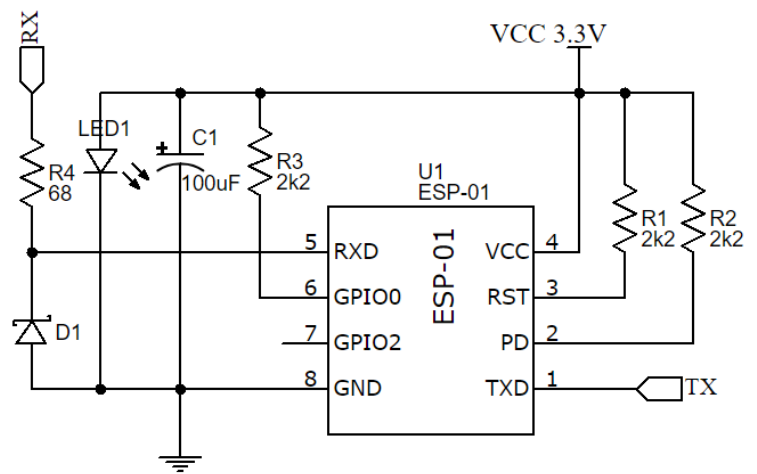

Gambar 4. Rangakaian ESP-01

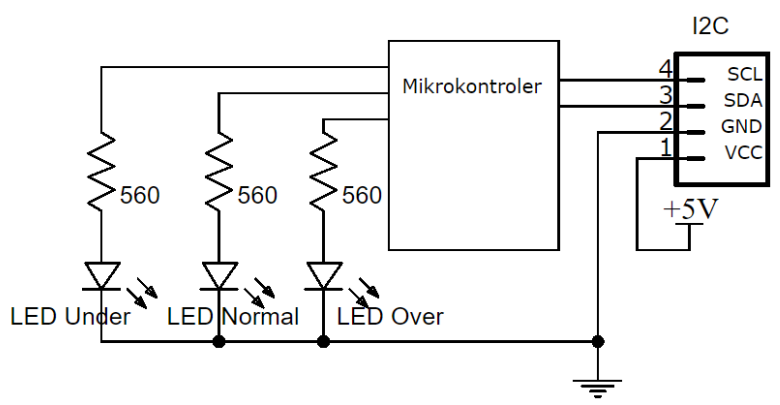

Gambar 5. Perancangan LCD

\subsubsection{Perancangan Rangkaian Display dan LED Indikator}

LCD berfungsi untuk menampilkan karakter dan nilai. Dalam perancangan ini menggunakan sebuah layar LCD 16x2 yang merupakan LCD dua baris dengan setiap barisnya terdiri dari 16 karakter. LCD ini dihubungkan dengan driver I2C untuk memudahkan komunikasi dari mikrokontroler. Sedangkan lampu indikator menggunakan 3 buah LED yang berwarna kuning sebagai indikator under, LED hijau sebagai indikatr normal, dan LED merah sebagai indikator over voltage. Ketiga LED tersebut akan aktif apabila diberi digital output high dari mikrokontroler atau tegangan 3,3Volt. Gambar perancangan LCD dan indikator LED ditunjukkan pada Gambar 5.

\subsection{Algoritma dan Diagram Alir Sistem}

Pada bagian ini akan dijelaskan algoritma dan diagram alir dari masing-masing sub sistem yang ada dalam sistem yang dirancang.

\subsubsection{Algoritma dan Diagram Alir Pembacaan Sensor}

Pada bagian ini diperlihatkan algoritma pembacaan sensor sebagai berikut : a. Mulai.

b. Inisialiasi I/O dan variabel.

c. Baca nilai ADC sensor ZMPT101B.

d. Melakukan delay pembacaan sensor sebanyak 50 kali.

e. Menghitung nilai magnitude.

f. Memberikan filter pada nilai magnitude.

g. Kalibrasi dengan nilai pengali.

h. Mendapatkan Nilai tegangan AC actual

i. Selesai

Sedangkan diagram alirnya diperlihatkan pada Gambar 6.

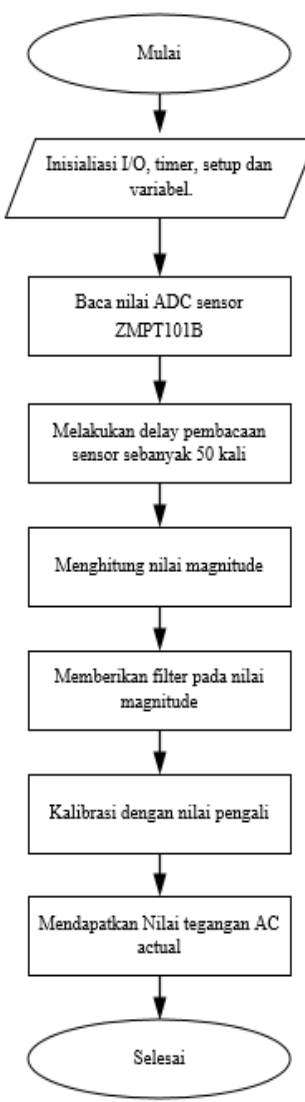

Gambar 6. Diagram alir pembacaan sensor ZMPT101B

\subsubsection{Algoritma dan Diagram Alir Kondisi Tegangan}

Pada bagian ini dideskripsikan algoritma penentuan kondisi tegangan, sebagai berikut.

a. Mulai.

b. Memasukkan nilai batas under $215 \mathrm{~V}$ dan over $225 \mathrm{~V}$.

c. Membaca nilai tegangan dari sensor (kirim_voltage)

d. Penentuan kondisi untuk relay :

- Jika kirim_voltage $>=225$, maka relay on dan led over menyala

- Jika kirim_voltage $>215$ dan kirim_voltage $<225$, maka relay off dan led normal menyala.

- Jika kirim_voltage $<=215$, maka relay on dan led under menyala. 
e. Mengirimkan pembacaan sensor dan kondisi ke database

f. Selesai

Sedangkan diagram alirnya ditunjukkan oleh Gambar 7.

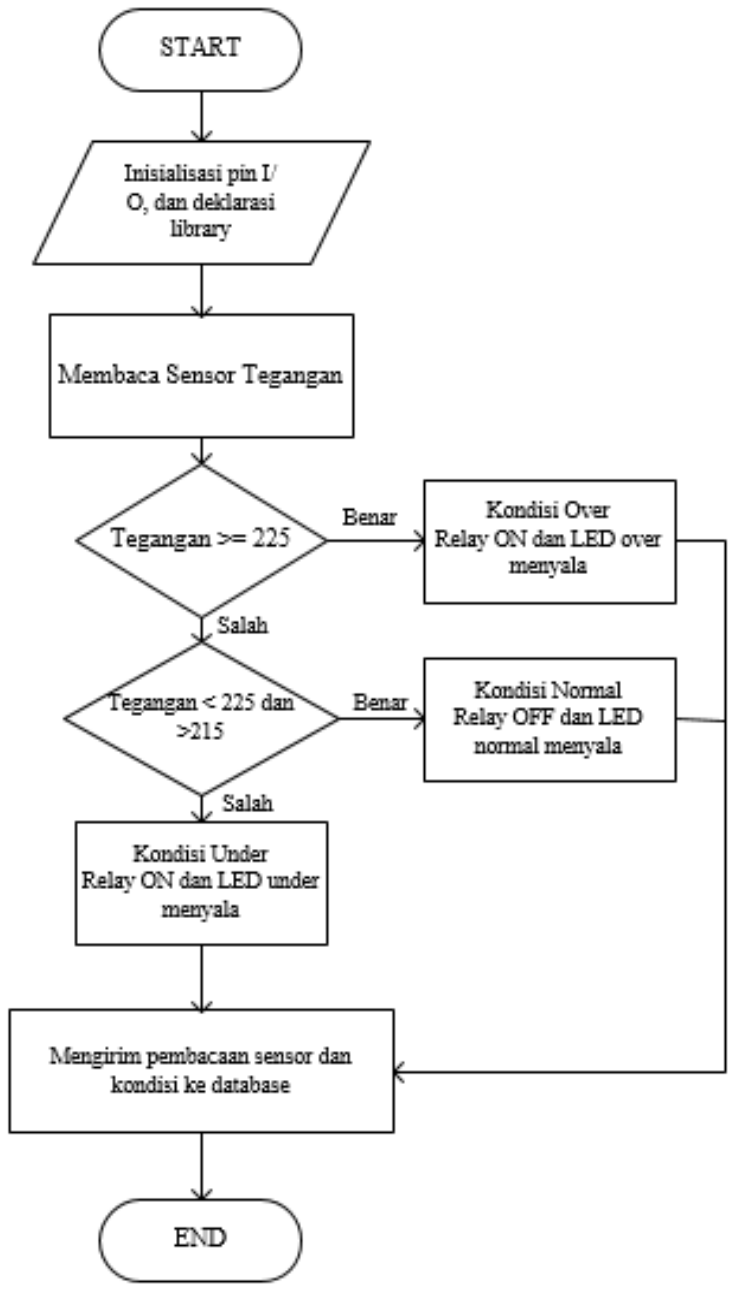

Gambar 7. Diagram alir penggerakkan servo

\subsection{Perancangan Perangkat Lunak}

\subsubsection{Pemrograman Pembacaan Sensor}

a. Pengukuran magnitude tegangan ac bedasarkan T/4 delay OSG (Orthogonal Signal Generator)

Persamaan (3) menunjukkan bahwa besarnya sinusoidal sinyal yang tertunda oleh $1 / 4$ periode sama dengan cosinus nilai dari sudut saat ini. Amplitudo atau besarnya a sinyal dapat diungkap dengan menggunakan identitas trigonometri di persamaan (4)[5].

$\sin \left(\theta-\frac{\pi}{4}\right)=\cos (\theta)$

$A(t)=\sqrt{\left(A_{m} \sin (\theta)\right)^{2}+\left(A_{m} \cos (\theta)\right)^{2}}$

$A(t)=A_{m}$
Pengambilan sampel frekuensi yang digunakan dalam kasus ini adalah $10 \mathrm{kHz}$, untuk pengambilan sampel sinyal tegangan, yang berarti gelombang sinus $50 \mathrm{~Hz}$ periodik akan diambil sampelnya 200 sampling data setiap periode. Memperoleh $1 / 4$ penundaan periode berarti sinyal harus ditunda 50 sampel jika sinyal tersebut diasumsikan sekitar $50 \mathrm{~Hz}$ frekuensi. Komunikasi data menggunakan komunikasi serial oleh modul ESP-01 untuk mengirimkan data pada interface.

\section{b. Eksponensial Filter}

Filter eksponensial adalah filter yang sederhana namun cukup kuat untuk memberikan hasil yang baik, Persamaan (6) mewakili persamaan filter eksponensial. Filter eksponensial memiliki parameter yaitu nilai $\alpha$. Nilai $\alpha$ dapat dipilih dalam rentang 0 hingga 1 . Jika nilai $\alpha$ semakin besar besar hasil pemfilteran kurang halus, tetapi respons filter adalah lebih cepat. Semakin kecil $\alpha$ memberikan hasil penyaringan yang halus, tetapi respons filter lebih lambat. Filter eksponensial adalah dipilih karena hasil yang halus diinginkan. Dengan menggunakan filter eksponensial dengan $9.995 \times 10^{-4}$ untuk nilai $\alpha$ dan metode perhitungan fix point, waktu eksekusi lebih efisien dan lebih cepat [5]. Persamaannya adalah sebagai berikut [9][10]:

$$
\begin{array}{ll}
X(t)=\alpha u(t) & +(1-a) X(t-1) \\
\text { Dengan : } & \\
u(t) & \text { : Data sebenarnya } \\
X(t) & \text { : Data hasil filter } \\
X(t-1) & \text { : Data hasil filter sebelumnya }
\end{array}
$$

\subsubsection{Pemrograman Kondisi}

Pemrograman kondisi merupakan logika untuk menentukan kondisi tegangan apabila memenuhi kriteria under voltage, normal, dan over voltage. Setelah kondisi ditentukan maka hasilnya akan ditampilkan pada LCD dan indikator led. Kondisi saat under voltage tegangan dibawah $216 \mathrm{~V}$ dengan relay dan indikator under menyala. Untuk normal voltage tegangan $216 \mathrm{~V}$ sampai $224 \mathrm{~V}$ dengan relay mati dan indikator normal menyala. Sedangkan untuk over voltage tegangan diatas $224 \mathrm{~V}$ dengan relay menyala dan indikator over menyala.

\subsubsection{Pemrograman ESP-01}

Aktivasi komunikasi wireless dilakukan untuk berkomunikasi antara alat dengan server yang ada pada jaringan internet. ESP-01 dihubungkan pada pin PB10 dan PB11 sebagai TX dan RX. Untuk itu dibutuhkan beberapa perintah yaitu program untuk mengkoneksikan jaringan dan program untuk mengirimkan data. 


\section{Hasil dan Analisis}

\subsection{Kalibrasi Sensor Tegangan ZMPT101B}

Pengaturan trimpot dilakukan sebagai kalibrasi awal agar gelombang keluaran pengkondisi sinyal sesuai dengan kriteria input mikrokontroler STM32F103C8T6. Hasil kalibrasi ditunjukkan pada Tabel 2, dimana masing-masing tegangan memiliki Vpp yang berbeda untuk keperluan pembacaan tegangan sensor ZMPT101B. Hasil tersebut sudah sesuai dengan keperluan mikrokontroler.

Tabel 2. Kalibrasi sensor ZMPT101B

\begin{tabular}{clll}
\hline Tegangan $(\mathbf{V})$ & Vpp & Vmax & Vmin \\
\hline 0 & 0.08 & 1.72 & 1.64 \\
10 & 0.1 & 1.74 & 1.64 \\
20 & 0.12 & 1.74 & 1.62 \\
30 & 0.18 & 1.78 & 1.6 \\
40 & 0.18 & 1.78 & 1.6 \\
50 & 0.2 & 1.78 & 1.58 \\
60 & 0.24 & 1.8 & 1.56 \\
70 & 0.28 & 1.84 & 1.56 \\
80 & 0.32 & 1.84 & 1.52 \\
90 & 0.36 & 1.86 & 1.5 \\
100 & 0.38 & 1.88 & 1.5 \\
110 & 0.4 & 1.88 & 1.48 \\
120 & 0.44 & 1.9 & 1.46 \\
130 & 0.48 & 1.92 & 1.44 \\
140 & 0.5 & 1.94 & 1.44 \\
150 & 0.54 & 1.94 & 1.4 \\
160 & 0.56 & 1.96 & 1.4 \\
170 & 0.6 & 1.98 & 1.38 \\
180 & 0.64 & 2 & 1.36 \\
190 & 0.66 & 2 & 1.34 \\
200 & 0.7 & 2.04 & 1.34 \\
210 & 0.72 & 2.04 & 1.32 \\
220 & 0.76 & 2.06 & 1.3 \\
230 & 0.78 & 2.08 & 1.3 \\
\hline
\end{tabular}

Tabel 3. Pengujian Sensor Tegangan ZMPT101B

\begin{tabular}{ccccc}
\hline No & $\begin{array}{c}\text { Tegangan } \\
\text { Multimeter }(\mathbf{V})\end{array}$ & $\begin{array}{c}\text { Tegangan Sensor } \\
\text { ZMPT101B }(\mathbf{V})\end{array}$ & Error (V) & $\begin{array}{l}\text { Error } \\
(\%)\end{array}$ \\
\hline 1 & 10 & 10 & 0 & $0.00 \%$ \\
2 & 20 & 20 & 0 & $0.00 \%$ \\
3 & 30 & 29 & 1 & $3.33 \%$ \\
4 & 40 & 40 & 0 & $0.00 \%$ \\
5 & 50 & 50 & 0 & $0.00 \%$ \\
6 & 60 & 61 & 1 & $1.67 \%$ \\
7 & 70 & 70 & 0 & $0.00 \%$ \\
12 & 80 & 80 & 0 & $0.00 \%$ \\
13 & 90 & 91 & 1 & $1.11 \%$ \\
14 & 100 & 100 & 0 & $0.00 \%$ \\
15 & 110 & 110 & 0 & $0.00 \%$ \\
16 & 120 & 121 & 1 & $0.83 \%$ \\
17 & 130 & 130 & 0 & $0.00 \%$ \\
18 & 140 & 141 & 1 & $0.71 \%$ \\
19 & 150 & 150 & 0 & $0.00 \%$ \\
20 & 160 & 160 & 0 & $0.00 \%$ \\
21 & 170 & 172 & 2 & $1.18 \%$ \\
22 & 180 & 180 & 0 & $0.00 \%$ \\
23 & 190 & 190 & 0 & $0.00 \%$ \\
24 & 200 & 201 & 1 & $0.50 \%$ \\
25 & 210 & 210 & 0 & $0.00 \%$ \\
26 & 220 & 220 & 0 & $0.00 \%$ \\
27 & 230 & 229 & 1 & $0.43 \%$ \\
28 & 185 & 185.22 & 0.22 & 0.119 \\
29 & 190 & 190.14 & 0.14 & 0.074
\end{tabular}

Tabel 3. Lanjutan

\begin{tabular}{lllll}
\hline 30 & 195 & 195.51 & 0.51 & 0.262 \\
31 & 200 & 200.88 & 0.88 & 0.440 \\
32 & 205 & 205.36 & 0.36 & 0.176 \\
33 & 210 & 210.28 & 0.28 & 0.133 \\
34 & 215 & 215.65 & 0.65 & 0.302 \\
35 & 220 & 220.57 & 0.57 & 0.259 \\
36 & 225 & 225.04 & 0.04 & 0.018 \\
37 & 230 & 229.52 & 0.48 & 0.209 \\
\multicolumn{2}{l}{ Error rata - rata } & & $\mathbf{0 . 3 9 1}$ & $\mathbf{0 . 4 2 5}$ \\
\hline
\end{tabular}

\subsection{Pengujian Pembacaan Data Sensor Tegangan ZMPT101B}

Pengujian sensor tegangan ZMPT101B dilakukan dengan membandingkan tegangan AC yang terbaca oleh sensor melalui mikrokontroler dengan tegangan AC yang terbaca oleh multimeter digital. Hasil pengukuran dan pembacaan sensor tegangan masing-masing dapat dilihat pada Tabel 3. Berdasarkan Tabel 3 4ata-rata error pembacaan tegangan sensor yaitu sebesar $0.391 \mathrm{~V}$ atau $0.425 \%$.

\subsection{Pengujian Komunikasi ESP-01}

Pengujian ESP-01 menggunakan Wi-Fi dilakukan pada alat ini dengan pengujian mengirim data menggunakan program Arduino IDE . Berikut tampilan pengiriman dan penerimaan data menggunakan ESP-01 menuju server.

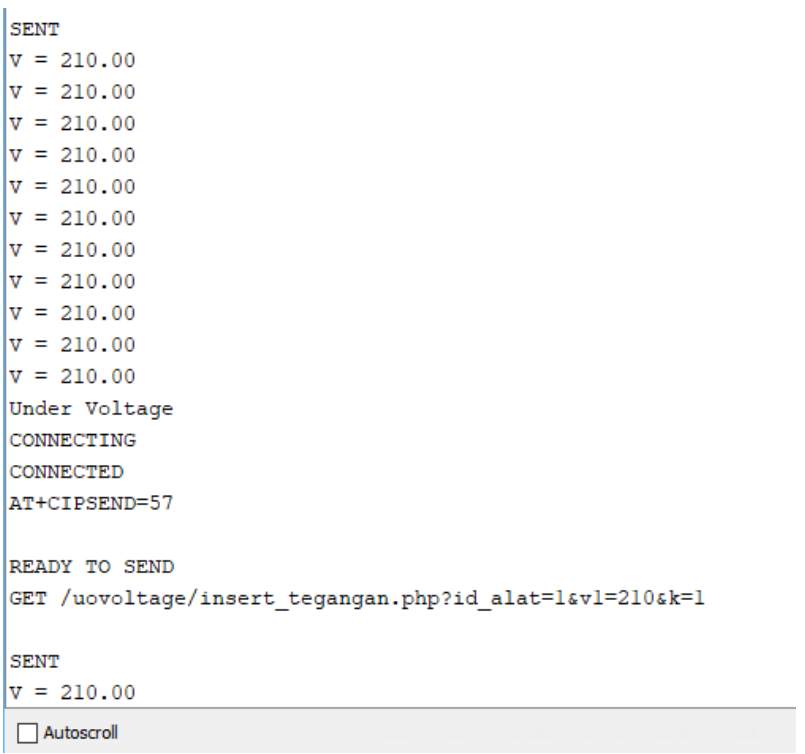

Gambar 8. Tampilan Pengiriman Data

Terlihat pada pengujian ESP-01 pengiriman dari serial monitor pada Arduino IDE menuju server pada Gambar 8 dan Gambar 9 menunjukkan hasil yang sesuai dimana data berhasil diterima pada server 


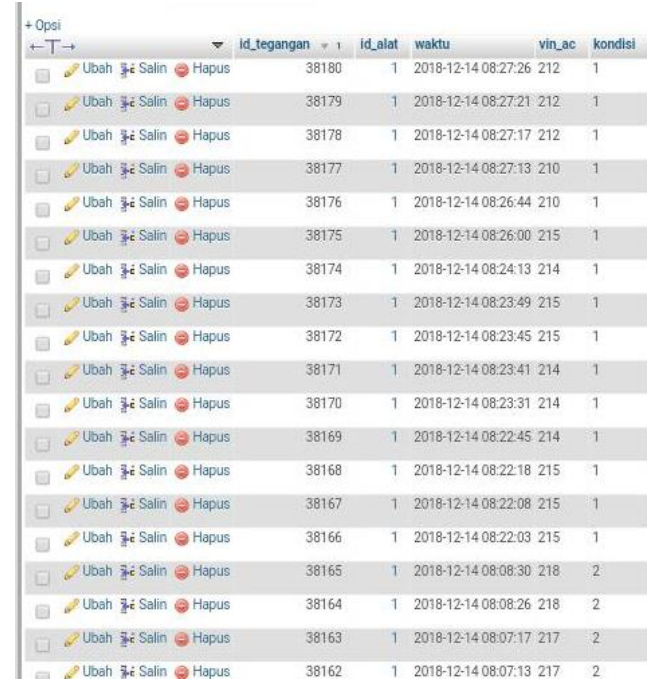

Gambar 9, Penerimaan Data pada Database.

\subsection{Pengujian Kondisi}

Pengujian kondisi dilakukan dengan menggunakan variable transformator untuk menyesuaikan tegangan masukan sesuai yang diinginkan. Kondisi tegangan terbagi menjadi 3, yaitu under voltage, normal voltage, dan over voltage. Pada Tabel 4 menunjukkan pengujian kondisi yang dilakukan menggunakan variable transformator dengan range tegangan $211 \mathrm{~V}$ sampai dengan $230 \mathrm{~V}$. Hasil pengujian sudah sesuai dengan program yang telah dirancang.

Tabel 4. Pengujian kondisi menggunakan variable transformator

\begin{tabular}{llllll}
\hline No. & $\begin{array}{l}\text { Tegangan } \\
\text { (Volt) }\end{array}$ & Relay & $\begin{array}{l}\text { Led } \\
\text { Under }\end{array}$ & $\begin{array}{l}\text { Led } \\
\text { Normal }\end{array}$ & Led Over \\
\hline 1 & 211 & Menyala & Nyala & Mati & Mati \\
2 & 213 & Menyala & Nyala & Mati & Mati \\
3 & 215 & Menyala & Nyala & Mati & Mati \\
4 & 217 & Mati & Mati & Menyala & Mati \\
5 & 219 & Mati & Mati & Menyala & Mati \\
6 & 221 & Mati & Mati & Menyala & Mati \\
7 & 223 & Mati & Mati & Menyala & Mati \\
8 & 225 & Menyala & Mati & Mati & Menyala \\
9 & 227 & Menyala & Mati & Mati & Menyala \\
10 & 229 & Menyala & Mati & Mati & Menyala \\
\hline
\end{tabular}

Gambar 10, Gambar 11, dan Gambar 12 menunjukkan tegangan terukur sebesar $212 \mathrm{~V}, 221 \mathrm{~V}$, dan $230 \mathrm{~V}$ dan masing-masing masuk ke dalam kondisi under voltage, normal voltage, dan over voltage. Layar LCD menampilkan informasi nilai tegangan yang diukur. Selain itu lampu indikator masing-masing menyala kuning, hijau, dan merah.

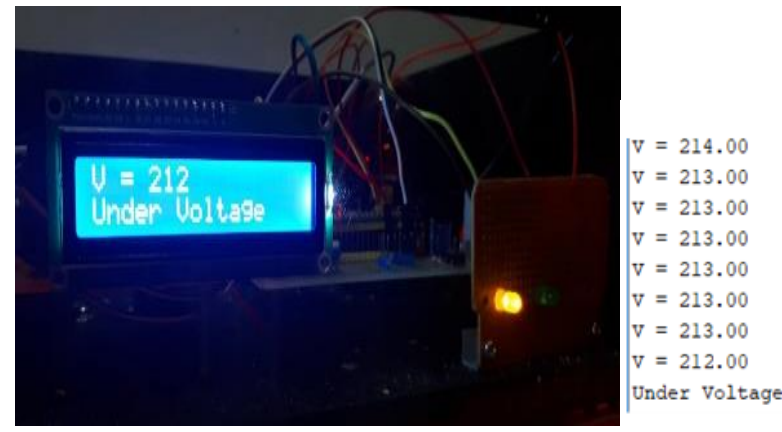

Gambar 10. Kondisi Under Voltage

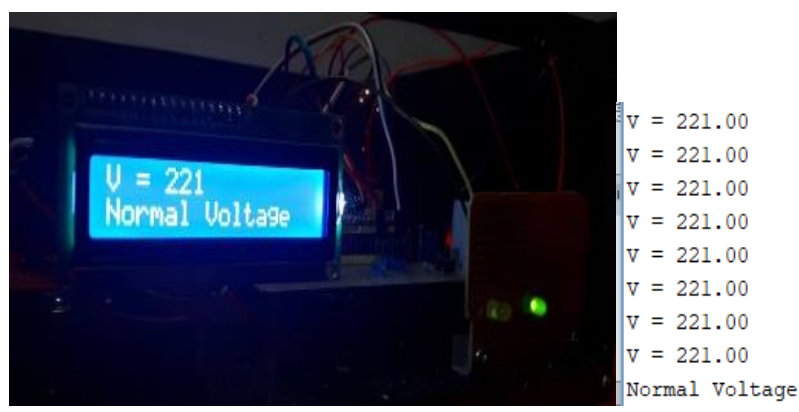

Gambar 11. Kondisi Normal Voltage

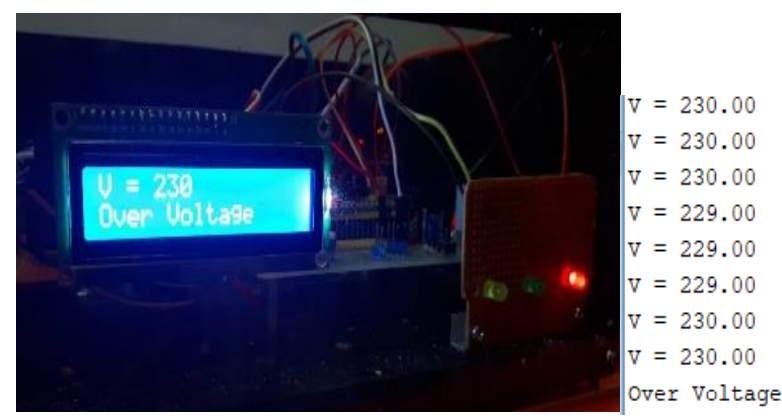

Gambar 12. Kondisi Over Voltage

Selain pengujian dengan memberikan variasi tegangan di laboratorium, penelitian ini juga melakukan pengujian lapangan yang berlokasi di rumah dengan sumber tegangan dari PLN. Pengujian ini dilakukan untuk mengetahui keandalan dari alat yang dirancang.

Gambar 13 menunjukkan sampel dari hasil pengujian yang dilakukan secara nonstop dalam beberapa hari. Data pengujian tersimpan dalam database. Dari hasil pengujian yang dilakukan, tegangan yang bersumber dari PLN pada rumah tersebut memiliki rata-rata stabil yaitu rata-rata tegangan $221 \mathrm{~V}-222 \mathrm{~V}$. Walaupun beberapa waktu ada yang mencapai over voltage. Tetapi gangguan hanya terjadi beberapa detik dan kembali normal. 


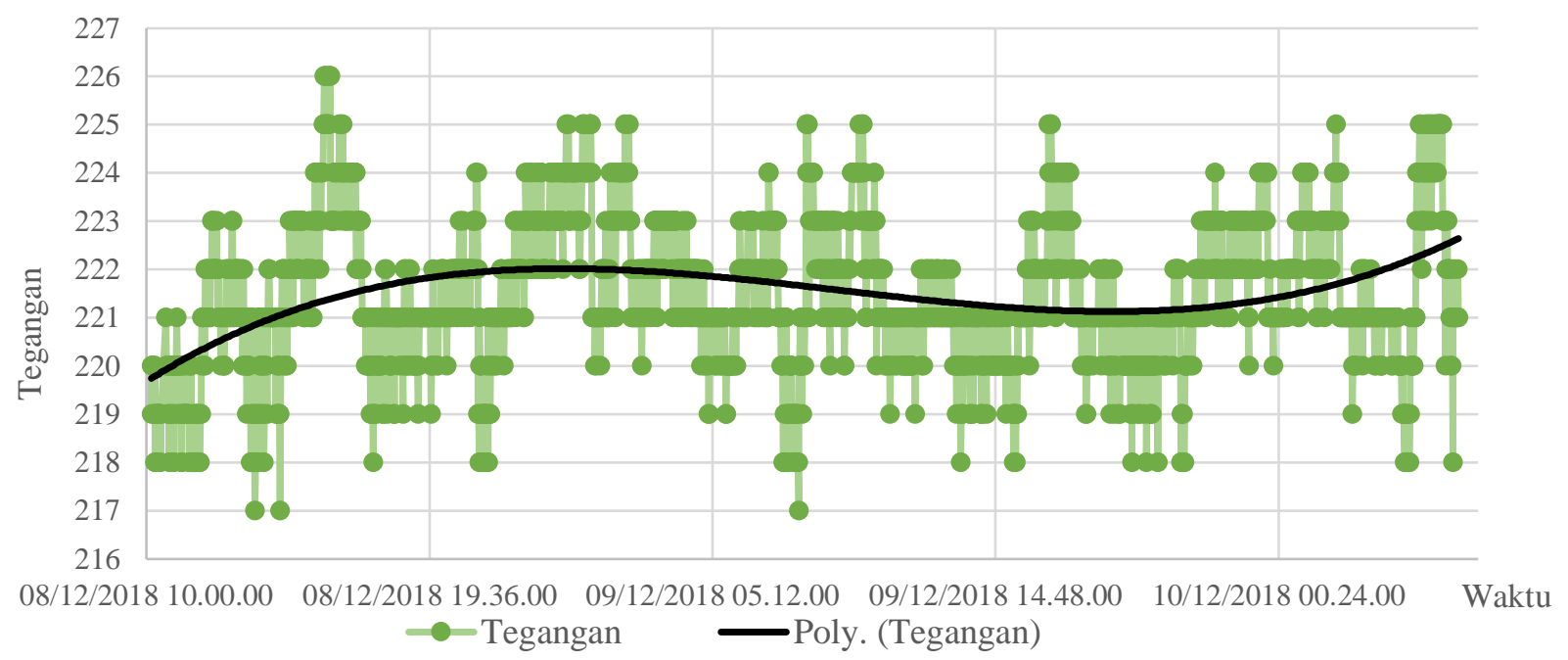

\section{Gambar 13 Grafik Hasil Pengujian Lapangan}

\section{Kesimpulan}

Dari hasil perancangan, pembuatan, pengujian dan analisis sistem over/under voltage relay berbasis mikrokontroler, didapatkan kesimpulan bahwa hasil pengukuran dan pembacaan sensor tegangan ZMPT101B menghasilkan rata-rata error pembacaan tegangan sensor yaitu sebesar $0.391 \mathrm{~V}$ atau $0.425 \%$. Error terjadi akibat noise dari keluaran ZMPT101B dan kalibrasi tegangan kerja yang biasa digunakan dalam sistem. Hasil kalibrasi sensor ZMPT101B memiliki VPP $=0.72 \mathrm{~V}$ yang dilakukan pada tegangan terukur AC $210 \mathrm{~V}$, dimana nilai VPP didapat dari selisih antara tegangan maksimum dan tegangan minimum gelombang keluaran sinus tersebut. Gelombang berosilasi pada tegangan minimum $1.32 \mathrm{~V}$ dan tegangan maksimum 2.04V. Tegangan offset sebesar 1,677 VDC, nilai ini tidak bernilai $1,65 \mathrm{~V}$ karena menyesuaikan tegangan referensi dari mikrokontroler.

Pada tegangan 216V sampai dengan 224V, alat akan bekerja pada kondisi normal voltage. Sedangkan dibawah $216 \mathrm{~V}$ maka alat pada kondisi under voltage dimana relay dan indikator led under akan bekerja. Dan apabila tegangan diatas $224 \mathrm{~V}$ maka alat dalam kondisi over voltage dimana relay dan indikator led over voltage akan bekerja. Data hasil pembacaan sensor dan kondisi berhasil dikirimkan ke database melalui ESP-01.

\section{Referensi}

[1]. Kementrian Energi dan Sumber Daya Mineral Direktorat Jenderal Ketenagalistrikan. "Statistika Ketenagalistrikan 2017". Edisi No.31, Tahun Anggaran 2018

[2]. E. Fuchs dan M.A. Masoum, Power quality in power systems and electrical machines. Academic press. 2011

[3]. M. Yingram dan S. Premrudeepreechacharn. "Investigation over/under-voltage protection of passive islanding detection method of distributed generations in electrical distribution systems". International Conference on Renewable Energy Research and Applications (ICRERA), 2012, hal. 1-5.

[4]. PT. PLN(Persero). Standar Perusahaan Listrik Negara No. $1: 1995$

[5]. I. Setiawan, T. Andromeda, M. Facta, dan S. Handoko, "Implementation and Performance Analysis of a Single Phase Synchronization Technique based on T / 4 Delay PLL," International Journal of Renewable Energy Research vol. 8, no. 1, 2018.

[6]. Ai-Thinker, "ESP-01 WiFi Module", 2015

[7]. STMicroelectronics, "RM0008 STM32F101xx, STM32F102xx, STM32F103xx, STM32F105xx and STM32F107xx Rev14," Power, October, 2011.

[8]. I. Abubakar, S. N. Khalid, M. W. Mustafa, H. Shareef, dan M. Mustapha, "Calibration of ZMPT101B voltage sensor module using polynomial regression for accurate load monitoring," ARPN Journal of Engineering and Applied Science, Vol 2, No. 4, February 2017.

[9]. "NIST/SEMATECH e-Handbook of Statistical Methods". NIST. http://www.itl.nist.gov/div898/handbook/, diakses 23 Mei 2018

[10]. Nau, Robert. "Averaging and Exponential Smoothing Models"., http://people.duke.edu/ rnau/411avg.htm, diakses 26 Juli 2018. 